\title{
The Importance of Sociological Engagement in Public Policy
}

-Dipesh Kumar Ghimire ${ }^{1}$

\begin{abstract}
Some scholars believe that it is none of the business of sociology or social science to address social problem and formulate public policy. Lynd (1939) and Hempel (1965) argue that Sociology cannot contribute to setting the public policy and they also believes that the sociology cannot give important contribution in policy process. Is sociology cannot contribute in public policy? This article is especially focused in searching the answer one this question.

This article argues that sociological engagement has been advancing gradually in public policy. Sociology has been playing an important role in solving the subjects of public concerns legally and addressing the subject of public interests in an appropriate way.
\end{abstract}

\section{Key Words:}

Public Policy, Sociology, Agenda Setting, public sociology

\section{Introduction}

Some scholars believe that it is none of the business of sociology or social science to address social problem and formulate public policy. Lynd (1939) argues that 'it is not the business of sociologists to point out what ought to be done to address a social problem. Hempel (1965) also believes that the sociology cannot give important contribution in policy process. He dismissed the idea that sociologists can address the issue of 'what ought to be done'.

As said by Lynd (1939) and Hempel (1965), is this true that sociology cannot contribute in public policy? If it can then how is the status of sociological engagement in public policy? This article is especially focused in these two questions. This article is based on secondary data and information. Content analysis is the main tools of the data collection for this article.

I have divided this paper into five sections; introduction, importance of sociology in public policy, sociological engagement in public policy, implication in Nepal and finally conclusion.

1 Dipesh Kumar Ghimire is an Assistant Professor of Sociology in Central Department of Sociology, Tribhuvan University, Nepal. He has been doing research and writing on citizens' movements, democracy, social inclusion, governance and issues of corruption for more than one decade. He has MPhil degree in Sociology. Recently his book "Political Corruption in Nepal: A Socio-Structural Perspective" and "Society and Corruption: Causes, Dimensions and Consequences" has been published. He can be reached at dipesh.ghimire33@gmail.com 


\section{Importance of Sociology in public policy process}

Society is multi-diversified. It is divided into several class, region, gender, caste and race. The division of upper class, middle class and lower class can be seen. This diversified society has specific problems. Inequality, poverty and other social and national problem like ethnicity, racial, discrimination cannot be solved by economics and political science alone (Wilson 1993). These problems can be solved by public policy (Buraway2004). According to Buraway (2004), public sociology brings sociology into a conversation with publics, understood as people who are themselves involved in conversation ...public sociology strikes up a dialogic relation between sociologist and public in which the agenda of each is brought to the table, in which each adjusts to the other.

Buraway (2004) gave more emphasis on public sociology. According to him, female movement rose first and then the sociology developed the gender perspective. World has already headed to globalization while sociology has just tried to realize this. Society market seems to be in one side while sociologist seems to be in another. Public sociology is important to address this issue.

Sociology can analyze the issues of inter-class, inter-religion, inter-groups relationship through multidimensional perspectives (Wilson 1993). An important role of the sociologist as a social scientist is the ability to capture and analyze the perspectives of different groups on similar different social issues. Sociology can position itself to have a real influence on shaping the national agenda in the ensuing years (Weiss 1993).

Similarly, according to Weiss (1993) sociology influences the public agenda through its theories and data, its concepts, ideas, and the findings of its research studies, sociology may help to shape what it is what the public thinks about it and what it is that government does.

Seeing in this way, not as said by Lynd (1939) and Hempel (1965), but the sociology plays an important role in public policy making process. According to Wilson (1993)it is not to say that sociologists cannot or should not address the issue of categorical value judgments in their studies of basic values and belief systems in society often a sociologist can point out the contradictions or inconsistencies in what are taken to be categorical judgment of values.

\section{Sociological engagement in public policy}

In recent time sociological engagement in public policy is very much essentially embedded. Public sociology is an American invention. Contemporary president of American Sociological Association Michael Burawoy had stated this in assembly in presidential address in 2004. The theme of the $85^{\text {th }}$ annual meeting of the American Sociological Association, "sociology and the public agenda" couples sociology and the public agenda with an innocuous (Weiss 1993). Public policy engages various public issues like health, education and transportation in its discipline. Burawoy (2004) has developed eleven different theses to show that public sociology can be a separate discipline in itself. This also helped sociology of public policy as a different discipline. 
Sociological engagement is seen in public policy in various ways. Earlier, public policy making process was of domestic concern but now it has gone to transnational and international sphere. Similarly, agenda setting and policy formulation was only the concern of sociologists. But, its implementation is also concerned these days. Also, some time ago, the role of agency was given importance while the role of social structure has been covered. Sociological engagement has been stated in these three main levels here.

\section{Agenda setting or policy formulation and Implementation}

Sociological engagement in public policy was mostly active in agenda setting and policy formulation in 1970s. (Kingdon, 1984 and Zahariadis 2007) gave emphasis on setting the agenda and alternatives of public policy. Kingdon (1984) emphasized on how are governmental agenda set? According to him, problems, policies and politics are three main streams important in agenda setting process. Each of the three processes; problem reorganization, generation of policy proposal and political events can serve as an impetus or as a constraint (Kingdon, 1984;19).

Zahariadis (2007) also gave emphasis on agenda setting in public policy process. He developed the framework containing five structural elements; problems, policies, politics, policy windows and policy entrepreneurs. Kingdon and Zahariadis have given more importance to political stream in policy process. According to Kindon (1984) political spheres are powerful agenda setters. A new administration, for instance, changes agendas all over town as it highlights its conceptions of problems and its proposals, and makes attention to subjects that are not among its high priorities much less likely.

However, in the present time, sociologists are involved not only in agenda setting and policy formulation process. They are also paying attention in implementation stage Ryan (1995). Barrett (2004) argues that the program implementation is concerned with what happens to a policy or program after it has been formulated implementation has been analyzed a serious obstacle to achieving desired program outcomes.

The implementation and policy formulation should be considered in conjunction as elements of policy design. This perspective treats implementation and policy formulation "as features of the design context rather than as arbiters of form and substance or determinants of success and failure (Linder and Peters 1990 cited by Ryan 1995).

\section{National vs. Transnational}

Before the extreme globalization era 1950s, policy process was only limited inside national boundaries Domestic. Policy could only be made with the involvement of actors. Cerny (2001) has said this as "Iron Triangles". Iron triangles represent in three sided policy process-politicians, bureaucrats and interest groups (Cerney 2001). Various sociologists have a view that, in this, the politicians only give attention to domestic issues in policy making process, bureaucrats do not want to go in conflict, and interest groups have their own business or other limited greed which limits policy formulation process to go in an appropriate way with iron triangles (Cerny 2001). 
In this context, due to the growth of international capital flows, cross-border price sensitivity and related technological developments, public policy making process has been shifted from national boundaries to transnational and international level. Cerny (2001) has said this as "Golden Pentangles." Golden pentangles represent highly stylized fashion of a five sided process along the three-sided iron triangles. One of the added two actors are international as well as transnational actors like IMF, World Bank, WTO, etc and another is cross-cutting structural factors like cross-border nongovernmental structures and actors, from transnational markets to civil society (Cerny 2001).

In this changed milieu, the engagement of sociologists in public policy has also changed. In the age of iron triangle, sociological engagement was with public policy in domestic level. Sociological engagement has also been globalized due to globalization. Now, sociologists are engaged in transnational and international level (Chabbott 1998). Think tanks are involved in domestic policy process (Stone 2007) while epistemic communities (Haas 1992) are engaged in international level. Though, (Ball 1998) has given emphasis on giving priority to local issues.

\section{Structure and agency based engagement}

Before 1990s, sociologists were focused on how the pursuit of individual's selfinterest affects politics and policy making process. Especially, political sociology and rational choice theories have focused on agency based analysis (Campbell 2002). Scholars have paid far less attention to how ideas that is, theories, conceptual models, norms, world views, frames, principled beliefs and the like, rather than self interests affect policy making process.

An earlier review of the literature on public policy domains lamented the fact that the little was known about the relative importance of ideas for policy making (Burstein 1991). Today, even some rational choice theorists have conceded that ideas matter (Levi 1997, North 1990). They are partially agreed with idea that getting more attention in public policy process than self-interest.

Social structures like, normative beliefs (Quirk 1990), identities (Hutchinson and smith 1994) values, norms and principled beliefs (Campbell, 2002) are more important insofar as it helps us better understand how actor define policy interest. However, other macro process; world culture (Meyer 1994, Thomas 1999), programmatic ideas (Campbell 2002) also affects the policy process.

The debate of agency vs. structure is very long in policy making process. But Campbell (2002) argues that the self-interest (agency) and idea (structure) are connected and affect each other in public policy making process. In this way, some have emphasized agency while the others emphasized structure. In the latest time however, some sociologists have linked both structure and agency to show an engagement.

It seems this way that sociology has strong engagement in public policy making process. Its involvement has been increasing in agenda making process and implementation, 
agency and structure and national and transnational level. In this age public sociology has been established as a strong discipline to address public issues.

\section{Implication in Nepal}

While the engagement of sociology is increasing in public policy, that has affected the developing countries like Nepal. The institutional development of sociology started in Nepal from 1981. Its institutional development is believed to start in 1981 when the Department of Sociology and Anthropology was established in Tribhuvan University (Subedi and Upreti, 2014). Since then, the sociological engagement has been increasing in public policy making process. A renowned sociologist of Nepal, Chaitanya Mishra was appointed as a member of National Planning Commission (NPC) in 2094. During this, he contributed in making policy of providing annual grants to all V.D.C.s of Nepal under "Afno gaun afai banau" program. Similarly, the concept of social security allowance was started by him legally for the first time. These two policies are taken as most important policies after the political movement of 1990. This makes clear about the importance of sociological engagement in policy making process.

Before 1950s in Nepal, policy maker were concerned only with agenda setting and policy formulation not to the implementation part. Especially the sociological engagement implementation can be seen from the earliest of 1990s.

Similarly, in the past public policy making processes were only limited to national level. Specially, the public policies which were formulated before 1951 were based on the engagement of very few high levels Rana family members (Pande, 2042). He further added;

A total of 26 major and 85/86 small offices under the Shree 3 Rana governed the state mechanism during 1903 to 2007 B.S. in Nepal...Their main responsibilities were to operate the daily governance as per the interest of the Prime Minister... All bureaucrats were responsible and accountable with Prime Minister and his family... the voice of the Prime minister became the policy and low of the state (p.9).

There was the role of national actor in first fifth year plan 2013 (Ghimire, 2057) but this has changed now. Now the policy of developing countries like Nepal is influenced by international actors. The seventh amendment of education act 2058 has been influenced by the world conference on education for all in Thailand in 1990 (Paudel, 2070). Similarly, health for all has also been influenced by the manifesto of Alma Ata international conference in 1978 (Onta 2004). Further, in the latest time, international community has been concerning and involving in most of the policy making processes in Nepal. The concern and pressure of international community can be seen in the root level in formulation of act like Money Laundering Act 2008 and economic liberalism.

\section{Conclusion}

Sociological engagement has been advancing gradually in public policy. Sociology has been playing an important role in solving the subjects of public concerns legally and 
addressing the subject of public interests in an appropriate way. I think that, the perspectives like agency and structure, national and transnational, agenda setting and implementation have made this strong. It is necessary in future to study about sociological engagement in policy making process of various subjects of public interest such as education, health, transportation, drinking water and sanitation. Also, sociologists need to concern about positive and negative effects of involvement of transnational community in domestic policy making process. Thus, as said by Wilson (1993), the future of the discipline may very well rest on the degree of influence that sociology wields in shaping the national agenda.

\section{Works Cited:}

Ball, Stephen. 1998. Big policies small world: An introduction to international perspectives in education policy. Comparative Education 34(2): 119-130.

Barrett, Susan M. 2004. Implementation Studies: Time for a Revival? Personal Reflections on 20 Years of Implementation Studies.Public Administration 82(4): 249-262.

Burstein P. 1991. Policy domains: Organization, Culture and Policy Outcomes. Annu. Rev. Social. 17:327-50.

Burawoy, Michael. 2007. For Public Sociology. In Public Sociology, pp. 23-64. California: University of California Press.

Campbell, John L. 2002. Ideas, Politics, and Public Policy. Annual Review of Sociology 28: 21-38.

Cerny, Phil. 2001. From "Iron Triangles" to "Golden Pentangles"? Globalizing the Policy Process. Global Governance 7: 397-410.

Chabbott, Collette. 1998. Constructing educational consensus: International development professionals and the World Conference on Education for All. International Journal of Educational Development 18(3): 207-218.

Ghimire, Harihar. 2057. Nepal ma Bikash ka Prayashharu. Sajha Prakashan : Kathmandu Nepal.

Haas, Peter M. 1992. Introduction: Epistemic Communities and International Policy Coordination. International Organization 46(1): 1-35.

Hempel, Carl G. 1965. Aspects of Scientific Explanation. New York: Free Press.

Hutchinson J, and Smith AD. 1994. Nationalism. New York; Oxford University Press.

Kingdon, John W. 1984. How Does an Idea's Time Come \& Wrapping Things Up. In Agendas, Alternatives and Public Policies. Boston: Little, Brown and Company.

Lynd, Robert S. 1939. Knowledge for What? The Place of Social Science in American Culture. Princeton, NJ: Princeton University Press.

Levi M. 1997. Consent, Dissent, and Patriotism. New York: Norton.

Meyer JW, 1994. Rationalization environments. In Institutional Environments and Organizations, ed. WR Scoot, JW Meyer, PP. 28-54, Newbury Park, CA: Sage.

North D. 1990.Institutions, Institutional Chane and Economic Performance. New York: Cambridge University Press. 
Onta Sharad. 2004. Rajyako Bhumika :Jana swasthya ko Dristikod Bata. Nepal ko Sandharva ma Samaj sasthriya Chintan. Ed. Meri Dosen and Pratyus Onta. pp. 97-124. Kathmandu: Social Science Baha:

Pande, B. 2044. Tes Bakhat ko Nepal Bhag-5. Lalitpur: Sajha Prakashan.

Paudel A. 2013. Corruption in School Management Handover Process. Transparency: Kathmandu: pp.27-30, Transparency International Nepal.

Quirk P. 1990.Deregulation and the Politics of Ideas in Congress. In Beyond Self-Interest, ed, JJ Mansbridge, pp. 183-99. Chicago: University Chicago Press.

Ryan, Neal. 1995. Unravelling Conceptual Developments in Implementation Analysis. Australian Journal of Public Administration 54(1): 65-80.

Stone, Diane.2007. Public Policy Analysis and Think Thanks. In Handbook of Public Policy Analysis: Theory, Politics, and Methods. Frank Fischer, Gerald J. Miller, and Mara S. Sidney, eds., pp. 149-157. New York: CRC Press.

Subedi M.S. and Devendra Upreti. 2014. The State of Sociology and Anthropology in Nepal. Kathmandu: Martin Chautari

Thomas GM. 1987. Institutional Structure. Newbury Park, CA: Sage

Weiss, Carol H. 1993. Can Sociology Play a Greater Role in Shaping the National Agenda.In Sociology and the Public Agenda. William Julius Wilson, ed.,pp.1-22. California: Sage Publications.

Wilson, William Julius. 1993. Can Sociology Play a Greater Role in Shaping the National Agenda. In Sociology and the Public Agenda. William Julius Wilson, ed. Pp. 1-22 California: Sage Publications.

Zahariadis, Nikolaos. 2007. The Multiple Streams Framework: Structure, Limitations, Prospects. In Theories of the Policy Process ( $2^{\text {nd }}$ edition). Paul A. Jabatier, ed., pp. 65-92. Boulder, Colorado: West view Press. 
